\title{
Optimization of Concentration of Medium Ingredients for Production of Citric Acid using Statistical Methods
}

\author{
M. U. Rahman*a, S. Gul ${ }^{b}$, A. A. Odhano ${ }^{a}$, I. Hafeez ${ }^{a}$ R. B. Tareen ${ }^{b}$ and M. M. Yasinzai ${ }^{b}$ \\ ${ }^{a}$ PCSIR Laboratories, P.O. Box 387, Mastung Road, Quetta, Balochistan, Pakistan and ${ }^{b}$ Department of Botany, \\ University of Balochistan, Quetta,Balochistan, Pakistan
}

\begin{abstract}
The concentration of medium ingredients was optimized by applying statistical methods for production of citric acid by locally isolated Aspergillus niger PCSIR-06. Box-bhenken design and response surface methodology were applied for designing experiment and statistical analysis of results. The Box-bhenken design limited the number of experiments to fifty four for studying possible interaction between the six medium ingredients i.e., Sucrose, $\mathrm{KH}_{2} \mathrm{PO}_{4}, \mathrm{NH}_{4} \mathrm{NO}_{3}, \mathrm{MgSO}_{4}$, zinc and iron. The statistical method predicted maximum citric acid yield of $108.69 \mathrm{~g} / \mathrm{l}$ with medium ingredients concentration Sucrose $149.92 \mathrm{~g} / 1, \mathrm{KH}_{2} \mathrm{PO}_{4} 1.25 \mathrm{~g} / 1, \mathrm{NH}_{4} \mathrm{NO}_{3}, 4.66 \mathrm{~g} / 1, \mathrm{MgSO}_{4} 0.15 \mathrm{~g} / 1, \mathrm{Zn} 24.00$ $\mathrm{mg} / \mathrm{l}, \mathrm{Fe} 0.21 \mathrm{mg} / \mathrm{l}$. The verification run confirmed the predicted yield with the given concentration of medium ingredients. These studies successfully demonstrated the use of Box-Bhenken experimental design for the optimization of nutrient concentration for maximum yield of citric acid.
\end{abstract}

Key words: Optimize, Medium, Citric acid, Box-bhenken design, Response surface methodology

\section{Introduction}

Citric acid (2-hydroxy-1,2,3-propanetricarboxylic acid) is produced by fermentation (Roukas and Kotzekidou 1997; Hang and Woodams, 1998). Citric acid is one of the fermentation products with an estimated annual production of about $1,000,000$ tons, the highest level of production worldwide (Soccol et al., 2003). Considerable amount of citric acid is required in several industrial processes (Jianlong, 2000). The food industry consumes about $70 \%$ of the total citric acid production, while other industries consume the remaining 30\% (Yokoya, 1992; Pandey et al., 2001). Citric acid is used in food, beverage, pharmaceutical, chemical, cosmetic and other industries for applications such as acidulation, antioxidation, flavour enhancement, preservation, plasticizer and as a synergistic agent (Sarangbin et al., 1993; Shankaranand and Lonsane, 1994; Suzuki et al.,1996). The filamentous fungus Aspergillus niger is the most commonly used microorganism for citric acid production (Roukas 1999).

The excretion of intermediates of the TCA cycle (organic acids; for instance citrate, oxalate or succinate) is a characteristic feature of many anamorphic fungal species, such as Aspergillus spp. and Penicillium spp. Excretion of organic acids is observed in natural habitats (Gadd, 2004) and during growth on solid/liquid media in the laboratory (Foster, 1949). Commercial production of citric acid is generally by submerged fermentation using the filamentous fungus Aspergillus niger (Röhr et al., 1983; Vandenberghe et al., 2000, Roukas 1999).

The demand for citric acid production is increasing faster than its production and hence more economical processes are required. The growth and production of citric acid is greatly affected by medium composition, fermentation parameters and stimulators. The medium components nitrogen, carbon and phosphorus and metal ions play critical role in production of citric acid by Aspergillus sp. (Kristiansen and Sinclair, 1978).

In development of industrial processes optimization of conditions has vital importance. One variable at a time (OVAT), a classical optimization methodology is most frequently used. It is time and effort consuming. Moreover, it also lacks the study of interaction between variables (Haaland, 1989). In order to optimize biotechnological processes, the statistical

\footnotetext{
*Corresponding author: E-mail: mujeeb_biotech@yahoo.co.uk,mujeeb.butt@hotmail.com
} 
approaches provide cost-effective way out as they provide pre planned methods through which interaction between variables can easily be calculated (Haaland, 1989; Gupta et al., 2002). Response surface methodology (RSM) is one of the useful models for studying the effect of several factors influencing the responses by varying them simultaneously and carrying out limited number of experiments. Keeping in view of the above facts, present study was designed to optimize the medium ingredients concentration that play important role in growth of fungus and secretion of metabolic products. In order to study the concentration effects and optimization of concentration of the different medium ingredients on yield of citric acid, Box-Behnken design (1960) and response surface methodology (Deshayes, 1980; Metthews et al., 1981) were applied.

\section{Materials and Methods}

\section{Microorganism}

Aspergillus niger PCSIR-06 isolated by Rahman et al. (2008) was used in present studies.

\section{Organism maintenance}

The culture of Aspergillus niger was maintained on sterilized potato dextrose agar medium (Potato Extract of $200 \mathrm{~g} / \mathrm{l}$, Dextrose $20 \mathrm{~g} / \mathrm{l}$ and Agar $15 \mathrm{~g} / \mathrm{l}), \mathrm{pH} 4.5$ and stored at $5^{\circ} \mathrm{C}$ in the refrigerator. All the culture media, unless other wise stated, were sterilized in autoclave at $15 \mathrm{lbs} / \mathrm{inch}^{2}$ pressure $\left(121^{\circ} \mathrm{C}\right)$ for $15 \mathrm{~min}$.

\section{Inoculum Preparation}

The spores of $A$. niger PCSIR-06 were produced in $250 \mathrm{ml}$ Erlenmeyer flasks containing $40 \mathrm{ml}$ PDA medium. The medium was inoculated with spores from the stock culture and incubated at $28^{\circ} \mathrm{C}$ for seven days. The spores were recovered by stirring using a solution of Tween $800.01 \%$.

The suspension obtained, containing $10^{8}$ spores $/ \mathrm{ml}$ was used as inoculum.

\section{Fermentation technique}

Citric acid production experiments were carried out using sterilized medium containing glucose, $\mathrm{NH}_{4} \mathrm{NO}_{3}, \mathrm{KH}_{2} \mathrm{PO}_{4}$ and $\mathrm{MgSO}_{4}$ as per model design in TUNAIR ${ }^{\mathrm{TM}}$ Cell growth Shake Flask System, Shelton Scientific-IBI, working vol- ume $500 \mathrm{ml}$, shaking speed $200 \mathrm{rpm}$ and filter size 0.22 micron nitrocellulose. $5 \% \mathrm{v} / \mathrm{v}$ inoculum was used for inoculating the medium through out the studies. The whole system was incubated at $30 \pm 1^{\circ} \mathrm{C}$ for $168 \mathrm{hrs}$.

\section{Analytical methods}

After the completion of each experiment the fermented broth was centrifuged at $10,000 \mathrm{rpm}$ for 10 minutes and the supernatant was used for analysis.

\section{Estimation of Citric Acid}

Citric acid was estimated by using pyridine- acetic anhydride method as reported by Marrier and Boulet (1956). One ml of the diluted culture filtrate along with $1.30 \mathrm{ml}$ of pyridine was added in the test tube and swirled briskly. Then $5.70 \mathrm{ml}$ of acetic anhydride was added in the test tube. The test tube was placed in a water bath at $32^{\circ} \mathrm{C}$ for $30 \mathrm{~min}$. The absorbance was measured by double beam spectrophotometer HITACHI $\mathrm{U} 2000$ at $405 \mathrm{~nm}$ and citric acid contents of the sample were estimated by comparison with reference to the standard. The percentage of citric acid was determined.

\section{Experimental design and optimization by RSM}

Response surface methodology is a group of experimental techniques to evaluate relationship between cluster of controlled experimental factors and measured responses according to one or more selected criteria. The variables selected were Sucrose, $\mathrm{KH}_{2} \mathrm{PO}_{4}, \mathrm{NH}_{4} \mathrm{NO}_{3}, \mathrm{MgSO}_{4}, \mathrm{Zn}$ and Fe. BoxBehnken design (Box and Behnken, 1960) was applied to describe the nature of the response surface in the experimental region and to identify the optimum medium components concentration for maximum yield of citric acid.

The actual and coded values along with units for different variables are shown in Table I.

Table II presents the design matrix for medium components sucrose, $\mathrm{KH}_{2} \mathrm{PO}_{4}, \mathrm{NH}_{4} \mathrm{NO}_{3}, \mathrm{MgSO}_{4}, \mathrm{Zn}$ and Fe consisting of 54 trials to study the yield of citric acid. Each variable was studied on three levels, coded $-1,0$ and +1 for low, middle and high values.

In order to predict the optimal point, a second order polynomial function was fitted to correlate the relationship between the independent variable and the response citric acid yield. For six factors, the equation was 
Table I: The coded and actual values of the factors in Box-Behnken design

\begin{tabular}{l|c|c|c|c|c|c|c|c}
\hline Factors & Name of factors & Units & Low coded & Low actual & Centre coded & Centre actual & High coded & High actual \\
\hline $\mathrm{A}$ & $\mathrm{Sucrose}$ & $\mathrm{gl}^{-1}$ & -1 & 50.00 & 0 & 100.00 & 1 & 150.00 \\
$\mathrm{~B}$ & $\mathrm{KH}_{2} \mathrm{PO}_{4}$ & $\mathrm{gl}^{-1}$ & -1 & 1.25 & 0 & 3.13 & 1 & 5.00 \\
$\mathrm{C}$ & $\mathrm{NH}_{4} \mathrm{NO}_{3}$ & $\mathrm{gl}^{-1}$ & -1 & 1.25 & 0 & 3.13 & 1 & 5.00 \\
$\mathrm{D}$ & $\mathrm{MgSO}_{4}$ & $\mathrm{gl}^{-1}$ & -1 & 0.125 & 0 & 0.31 & 1 & 0.375 \\
$\mathrm{E}$ & $\mathrm{Zn}$ & $\mathrm{mgl}^{-1}$ & -1 & 6.00 & 0 & 15.00 & 1 & 24.00 \\
F & $\mathrm{Fe}$ & $\mathrm{mgl}^{-1}$ & -1 & 0.20 & 0 & 0.50 & 1 & 0.80 \\
\hline
\end{tabular}

$\mathrm{Y}=\beta_{0}+\beta_{1} \mathrm{~A}+\beta_{2} \mathrm{~B}+\beta_{3} \mathrm{C}+\beta_{4} \mathrm{D}+\beta_{5} \mathrm{E}+\beta_{6} \mathrm{~F}+\beta_{12} \mathrm{AB}+\beta_{13} \mathrm{AC}+$ $\beta_{14} \mathrm{AD}+\beta_{15} \mathrm{AE}+\beta_{16} \mathrm{AF}+\beta_{23} \mathrm{BC}+\beta_{24} \mathrm{BD}+\beta_{25} \mathrm{BE}+\beta_{26} \mathrm{BF}+$ $\beta_{34} \mathrm{CD}+\beta_{35} \mathrm{CE}+\beta_{36} \mathrm{CF}+\beta_{45} \mathrm{DE}+\beta_{46} \mathrm{DF}+\beta_{56} \mathrm{EF}+\beta_{11} \mathrm{~A}^{2}+\beta_{22} \mathrm{~B}^{2}$ $+\beta_{33} \mathrm{C}^{2}+\beta_{44} \mathrm{D}^{2}+\beta_{55} \mathrm{E}^{2}+\beta_{66} \mathrm{~F}^{2}$
Where $\mathrm{Y}$ is the measured response Citric Acid yield, $\beta_{\mathrm{o}}$ is the model constant, $\beta_{1}, \beta_{2}, \ldots . \beta_{6}$ are linear coefficient, $\beta_{11}, \beta_{22}$, $\beta_{33}, \beta_{44}, \beta_{55}, \beta_{66}$ are quadratic coefficient, $\beta_{12}, \beta_{13}, \ldots . \beta_{46}$ are cross product coefficient and A,B,C ..... F are coded independent variables.

Table II: Box-Behnken design for six factors influencing citric acid yield

\begin{tabular}{|c|c|c|c|c|c|c|c|c|c|}
\hline \multirow{2}{*}{$\begin{array}{l}\text { Std } \\
\text { order }\end{array}$} & \multirow[t]{2}{*}{ Design Id } & \multirow{2}{*}{$\begin{array}{l}\text { Run } \\
\text { order }\end{array}$} & \multirow{2}{*}{$\begin{array}{l}\text { Point } \\
\text { type }\end{array}$} & \multicolumn{6}{|c|}{ Factors } \\
\hline & & & & A & $\mathrm{B}$ & $\mathrm{C}$ & $\mathrm{D}$ & $\mathrm{E}$ & $\mathrm{F}$ \\
\hline 1 & 10 & 17 & IBFact & 0 & 1 & -1 & 0 & -1 & 0 \\
\hline 2 & 23 & 21 & IBFact & 0 & 0 & -1 & 1 & 0 & 1 \\
\hline 3 & 3 & 33 & IBFact & -1 & 1 & 0 & -1 & 0 & 0 \\
\hline 4 & 31 & 28 & IBFact & -1 & 0 & 0 & 1 & 1 & 0 \\
\hline 5 & 7 & 6 & IBFact & -1 & 1 & 0 & 1 & 0 & 0 \\
\hline 6 & 25 & 11 & IBFact & -1 & 0 & 0 & -1 & -1 & 0 \\
\hline 7 & 29 & 43 & IBFact & -1 & 0 & 0 & -1 & 1 & 0 \\
\hline 8 & 26 & 7 & IBFact & 1 & 0 & 0 & -1 & -1 & 0 \\
\hline 9 & 48 & 4 & IBFact & 1 & 0 & 1 & 0 & 0 & 1 \\
\hline 10 & 41 & 12 & IBFact & -1 & 0 & -1 & 0 & 0 & -1 \\
\hline 11 & 8 & 40 & IBFact & 1 & 1 & 0 & 1 & 0 & 0 \\
\hline 12 & 15 & 44 & IBFact & 0 & -1 & 1 & 0 & 1 & 0 \\
\hline 13 & 28 & 26 & IBFact & 1 & 0 & 0 & 1 & -1 & 0 \\
\hline 14 & 38 & 10 & IBFact & 0 & 1 & 0 & 0 & -1 & 1 \\
\hline 15 & 18 & 19 & IBFact & 0 & 0 & 1 & -1 & 0 & -1 \\
\hline 16 & 35 & 39 & IBFact & 0 & -1 & 0 & 0 & 1 & -1 \\
\hline 17 & 16 & 31 & IBFact & 0 & 1 & 1 & 0 & 1 & 0 \\
\hline 18 & 36 & 15 & IBFact & 0 & 1 & 0 & 0 & 1 & -1 \\
\hline 19 & 42 & 37 & IBFact & 1 & 0 & -1 & 0 & 0 & -1 \\
\hline 20 & 37 & 14 & IBFact & 0 & - & 0 & 0 & -1 & 1 \\
\hline 21 & 27 & 16 & IBFact & - & 0 & 0 & 1 & -1 & 0 \\
\hline 22 & 43 & 23 & IBFact & - & 0 & 1 & 0 & 0 & -1 \\
\hline 23 & 21 & 35 & IBFact & 0 & 0 & -1 & -1 & 0 & 1 \\
\hline 24 & 13 & 51 & IBFact & 0 & - & -1 & 0 & 1 & 0 \\
\hline 25 & 30 & 32 & IBFact & 1 & 0 & 0 & -1 & 1 & 0 \\
\hline 26 & 20 & 2 & IBFact & 0 & 0 & 1 & 1 & 0 & -1 \\
\hline 27 & 2 & 38 & IBFact & 1 & -1 & 0 & -1 & 0 & 0 \\
\hline 28 & 5 & 54 & IBFact & -1 & -1 & 0 & 1 & 0 & 0 \\
\hline 29 & 47 & 29 & IBFact & -1 & 0 & 1 & 0 & 0 & 1 \\
\hline 30 & 1 & 48 & IBFact & -1 & -1 & 0 & -1 & 0 & 0 \\
\hline
\end{tabular}


Table II: To be contd.

\begin{tabular}{l|c|c|l|c|c|c|c|c|c}
\hline Std & Design Id & \multirow{2}{*}{$\begin{array}{c}\text { Run } \\
\text { order }\end{array}$} & Point & \multicolumn{2}{|c}{ Factors } \\
\cline { 4 - 9 } & & type & A & B & C & D & E & F \\
\hline 31 & 14 & 42 & IBFact & 0 & 1 & -1 & 0 & 1 & 0 \\
32 & 33 & 34 & IBFact & 0 & -1 & 0 & 0 & -1 & -1 \\
33 & 39 & 8 & IBFact & 0 & -1 & 0 & 0 & 1 & 1 \\
34 & 46 & 41 & IBFact & 1 & 0 & -1 & 0 & 0 & 1 \\
35 & 12 & 20 & IBFact & 0 & 1 & 1 & 0 & -1 & 0 \\
36 & 32 & 53 & IBFact & 1 & 0 & 0 & 1 & 1 & 0 \\
37 & 6 & 27 & IBFact & 1 & -1 & 0 & 1 & 0 & 0 \\
38 & 22 & 52 & IBFact & 0 & 0 & 1 & -1 & 0 & 1 \\
39 & 17 & 49 & IBFact & 0 & 0 & -1 & -1 & 0 & -1 \\
40 & 4 & 22 & IBFact & 1 & 1 & 0 & -1 & 0 & 0 \\
41 & 44 & 1 & IBFact & 1 & 0 & 1 & 0 & 0 & -1 \\
42 & 19 & 3 & IBFact & 0 & 0 & -1 & 1 & 0 & -1 \\
43 & 24 & 46 & IBFact & 0 & 0 & 1 & 1 & 0 & 1 \\
44 & 9 & 30 & IBFact & 0 & -1 & -1 & 0 & -1 & 0 \\
45 & 11 & 5 & IBFact & 0 & -1 & 1 & 0 & -1 & 0 \\
46 & 45 & 9 & IBFact & -1 & 0 & -1 & 0 & 0 & 1 \\
47 & 34 & 25 & IBFact & 0 & 1 & 0 & 0 & -1 & -1 \\
48 & 40 & 45 & IBFact & 0 & 1 & 0 & 0 & 1 & 1 \\
49 & 0 & 24 & Centre & 0 & 0 & 0 & 0 & 0 & 0 \\
50 & 0 & 36 & Centre & 0 & 0 & 0 & 0 & 0 & 0 \\
51 & 0 & 13 & Centre & 0 & 0 & 0 & 0 & 0 & 0 \\
52 & 0 & 50 & Centre & 0 & 0 & 0 & 0 & 0 & 0 \\
53 & 0 & 18 & Centre & 0 & 0 & 0 & 0 & 0 & 0 \\
54 & 0 & 47 & Centre & 0 & 0 & 0 & 0 & 0 & 0 \\
\hline
\end{tabular}

Software Design-Expert (V.7.1.6, Statease, Minneapolis, 2008) was used for regression analysis of experimental data and graphical analysis. The quality of fit of the polynomial model equation was expressed by a coefficient of determination $\mathrm{R}^{2}$. The optimal concentrations of critical variables were obtained by analyzing contour plots. The statistical analysis of the model was represented in the form of Analysis of Variance (ANOVA). All the experiments were performed in triplicate and the mean values were subjected for analysis.

Software Design-Expert (V.7.1.6, Statease, Minneapolis, 2008) was used for regression analysis of experimental data and graphical analysis. The quality of fit of the polynomial model equation was expressed by a coefficient of determination $\mathrm{R}^{2}$. The optimal concentrations of critical variables were obtained by analyzing contour plots. The statistical analysis of the model was represented in the form of Analysis of
Variance (ANOVA). All the experiments were performed in triplicate and the mean values were applied for analysis.

\section{Results and Discussions}

\section{Model diagnostics}

Residual analysis (Fig. 1) was used to examine the adequacy of the presented model. Fig. 1a checks the lurking variables that may have influenced the response during the experiment. The plot showed a random scatter. Trends indicate a time related variable lurking in the background. Blocking and randomization provide insurance against trends ruining the analysis. Fig. $1 \mathrm{~b}$ represents the difference between the actual and predicted response. The residual differences were large enough when compared with the actual and predicted one. The difference was due to the presence of noise during the experimentation. Box-Cox plot provides a guide line for 
selecting the correct power law transformation. The lowest point on Box Cox plot represents the value of lambda $(\lambda)$ that results in the minimum residual sum of squares in the transformed model. Here the value of Lambda is ' $\lambda=1$ ' which means no transformation is required (Fig. 1c).
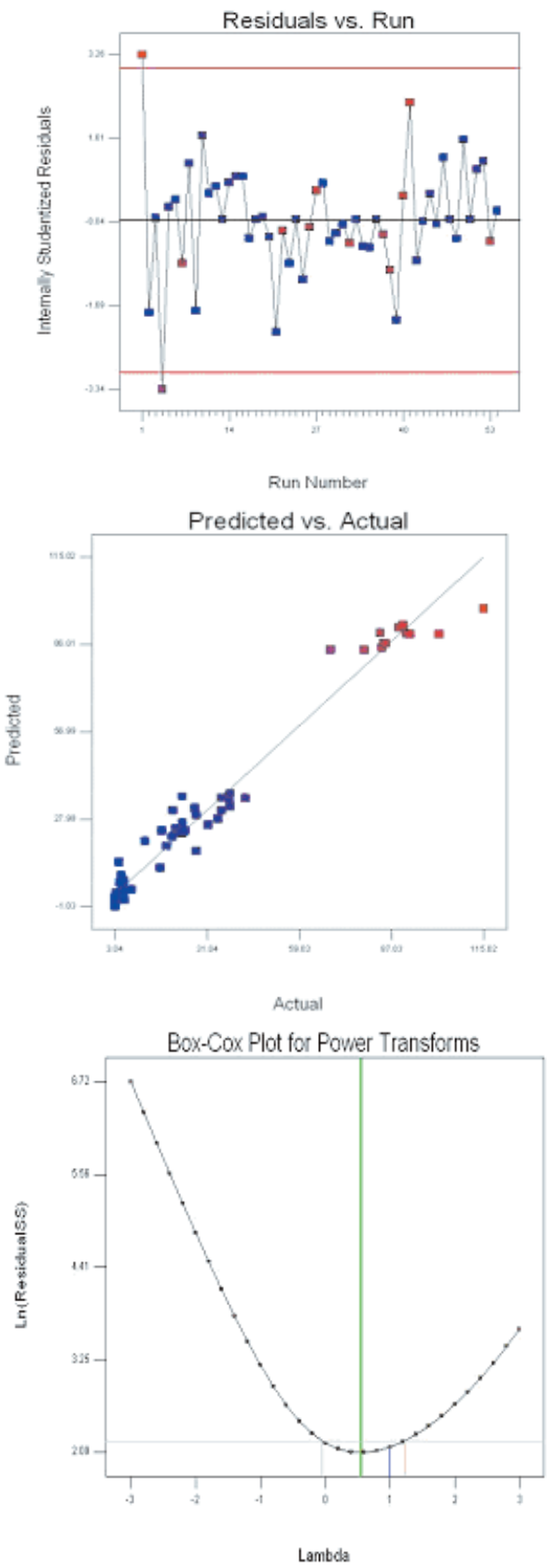

Fig. 1: Residual diagnostic of model for citric acid yield (a) Residual versus run order (b) Perdicted versus actual (c) Box-Cox Plot for power transformation Lambda Current $=1$, Best $=0.56$

Low C.I. $=$ - 0.05 High C.I. $=1.23$

\section{Response analysis of citric acid yield}

The model obtained by statistical package "Design expert" describing the response as function of variable was as follows:

Citric acid yield $=22.89+41.92 \mathrm{~A}-1.46 \mathrm{~B}-2.61 \mathrm{C}-2.25$

$\mathrm{D}-1.59 \mathrm{E}+1.21 \mathrm{~F}-0.47 \mathrm{AB}+0.24 \mathrm{AC}+1.107 \mathrm{AD}+2.15$

$\mathrm{AE}-2.9 \mathrm{AF}-2.70 \mathrm{BC}+0.91 \mathrm{BD}-1.01 \mathrm{BE}+0.48 \mathrm{BF}-5.08$ $\mathrm{CE}-4.05 \mathrm{CE}-4.11 \mathrm{CF}+0.01 \mathrm{DE}-0.45 \mathrm{DF}-4.54 \mathrm{EF}+$ $21.73 \mathrm{~A}^{2}+3.11 \mathrm{~B}^{2}+0.43 \mathrm{C}^{2}-1.80 \mathrm{D}^{2}+0.84 \mathrm{E}^{2}+1.36 \mathrm{~F}^{2}$

The results of 2 nd order response surface model fitted in the form of analysis of variance (ANOVA) are depicted in Table IV. The Model F-value of 27.21 implies the model is significant. There is only a $0.01 \%$ chance that a "Model F-Value" this large could occur due to noise. Values of "Prob $>F$ " less than 0.0500 indicate model terms are significant.

In this case $\mathrm{A}, \mathrm{CF}$ and $\mathrm{A}^{2}$ are significant model terms. Values greater than 0.1000 indicate the model terms are not significant. As there are many insignificant model terms, model reduction could improve the model. The "Pred R-Squared" of 0.7866 is in reasonable agreement with the "Adj RSquared" of 0.9303. "Adeq Precision" measures the signal to noise ratio. A ratio greater than 4 is desirable. Here the ratio of 16.785 indicates an adequate signal. This indicates a better precision and reliability of the experiment.

As stated earlier that p-values of "prob. > F" less than 0.0500 indicate significant model terms. Here in this particular case $\mathrm{A}, \mathrm{CF}$ and $\mathrm{A}^{2}$ are significant model terms. The "lack of fit value" of 82.77 is significant relative to pure error. A reduced model obtained describing the response as function of the most significant variables is as follows:

Citric Acid Yield $=22.89+41.91 \mathrm{~A}-4.11 \mathrm{CF}+21.73 \mathrm{~A}^{2}$

The relationship of controlled experimental factors and measured responses on the basis of different selected criteria are shown in Fig. 2-6.

The effect of combination of sucrose with other factors i.e., $\mathrm{KH}_{2} \mathrm{PO}_{4}, \mathrm{NH}_{4} \mathrm{NO}_{3}, \mathrm{MgSO}_{4}, \mathrm{Zn}$ and $\mathrm{Fe}$, in the form of response surface and contour plots are presented in Fig. 2. 

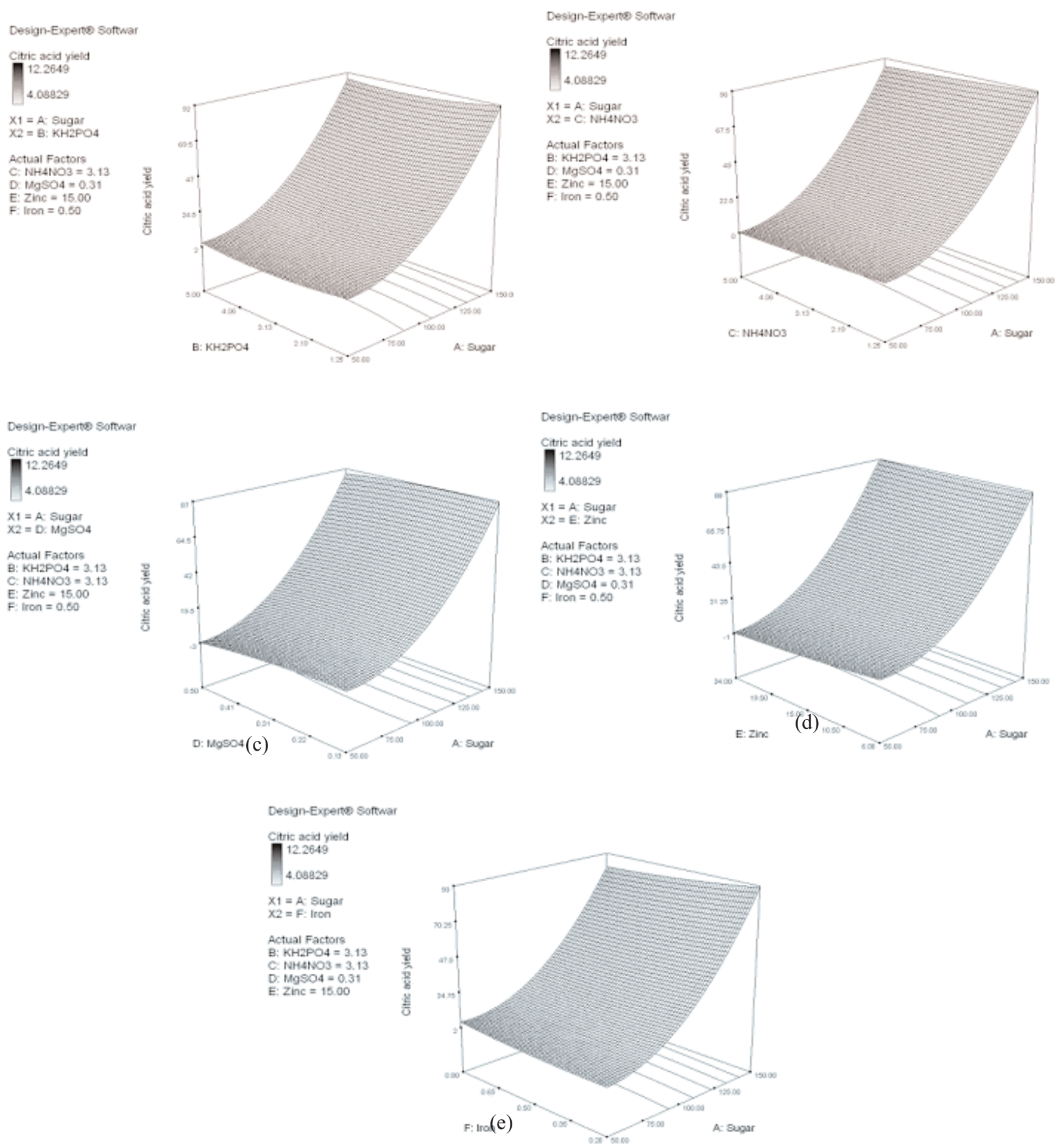

Fig. 2: Response surface and contour plot showing effect of sucrose in combination with other nutrient factors on citric acid yied by Aspergillus niger PCSIR-06
a) Sucrose $+\mathrm{KH}_{2} \mathrm{PO}_{4}$
b) Sucrose $+\mathrm{NH}_{4} \mathrm{NO}_{3}$
c) Sucrose $+\mathrm{MgSO}_{4}$,
d) Sucrose $+\mathbf{Z n}$
e) Sucrose + Fe 
The variation in concentration of all the individual ingredients with sucrose while keeping the rest of the factors at central level showed similar trends and revealed that sucrose is a major factor controlling the yield of citric acid in this case. The excessive concentration of carbon source is required for citric acid overflow during fermentation (Kristian and Sinclair, 1978).

The data regarding the variation in concentration in combinations of $\mathrm{KH}_{2} \mathrm{PO}_{4}$ with other individual nutrients while keeping the remaining nutrients at central points is presented in Fig. 3. The data revealed that maximum citric acid yield achieved was about $30 \mathrm{~g} / \mathrm{l}$ in combinations of $\mathrm{KH}_{2} \mathrm{PO}_{4}$ at maximum level with minimum level of $\mathrm{NH}_{4} \mathrm{NO}_{3}$ while rest of the ingredients kept at central points. These results confirmed the findings of Kristiansen and Sinclair (1979) that nitrogen must be limited to attain highest yields of citric acid. An appropriate balance of nitrogen and phosphate is important for the accumulation of citric acid in batch culture (Shu and Johnson, 1948). The other combinations showed mixed effect on yield of citric acid.

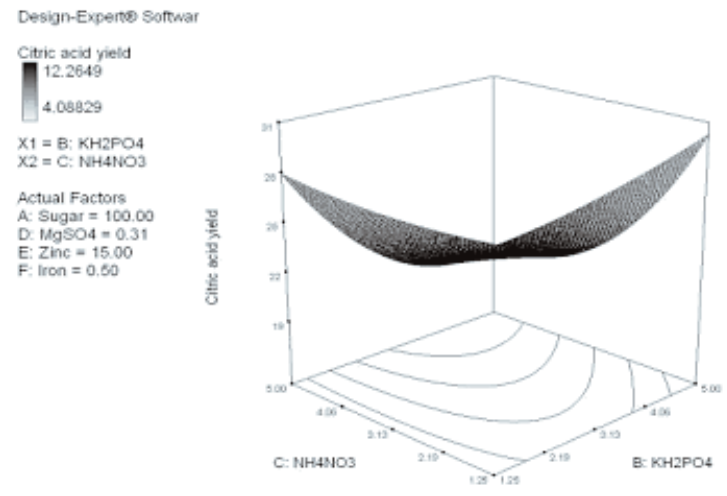

(a)

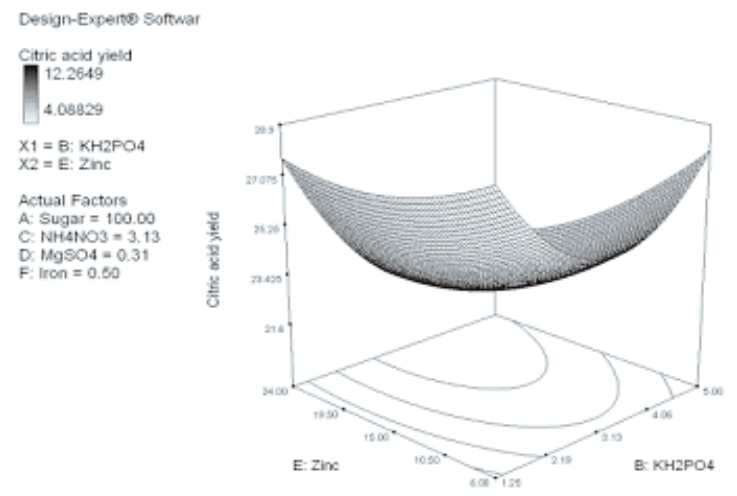

(c)
The response surface and contour plot of the effects of $\mathrm{NH}_{4} \mathrm{NO}_{3}$ concentration in combination with other nutrients i.e, $\mathrm{MgSO}_{4}, \mathrm{Zn}$ and $\mathrm{Fe}$ revealed that citric acid yield was possible in the range of $\simeq 10.0$ to $\simeq 30 \mathrm{~g} / 1$ (Fig. 4 ). Fig. 4 also unzip the fact that $\mathrm{NH}_{4} \mathrm{NO}_{3}$ a nitrogen source is required at maximum level with minimum levels of metals (Fe, $\mathrm{Zn}$ ) and $\mathrm{MgSO}_{4}$ for maximum yield of citric acid and vice versa. In defined media nitrogen is supplied as ammonium sulfate or ammonium nitrate. The advantage of ammonium salts is that they decrease $\mathrm{pH}$ as they are consumed, which is a prerequisite of citric acid production (Papagianni et al., 2005).

The data presented in Fig. 5 regarding variation in combination of $\mathrm{MgSO}_{4}$ with $\mathrm{Zn}$ and $\mathrm{Fe}$ showed more or less the same pattern of citric acid yield. The combination of $\mathrm{MgSO}_{4} \simeq$ $0.41 \mathrm{~g} / 1, \mathrm{Zn} \simeq 15.0 \mathrm{mg} / \mathrm{l}$ and $\mathrm{Fe} \simeq 0.5 \mathrm{mg} / 1$ while keeping rest of ingredients at central level gave maximum yield of citric acid.

The studies on optimization of $\mathrm{Zn}$ and iron keeping other nutrients at central point (Sucrose, $\mathrm{NH}_{4} \mathrm{NO}_{3}, \mathrm{KH}_{2} \mathrm{PO}_{4}$,
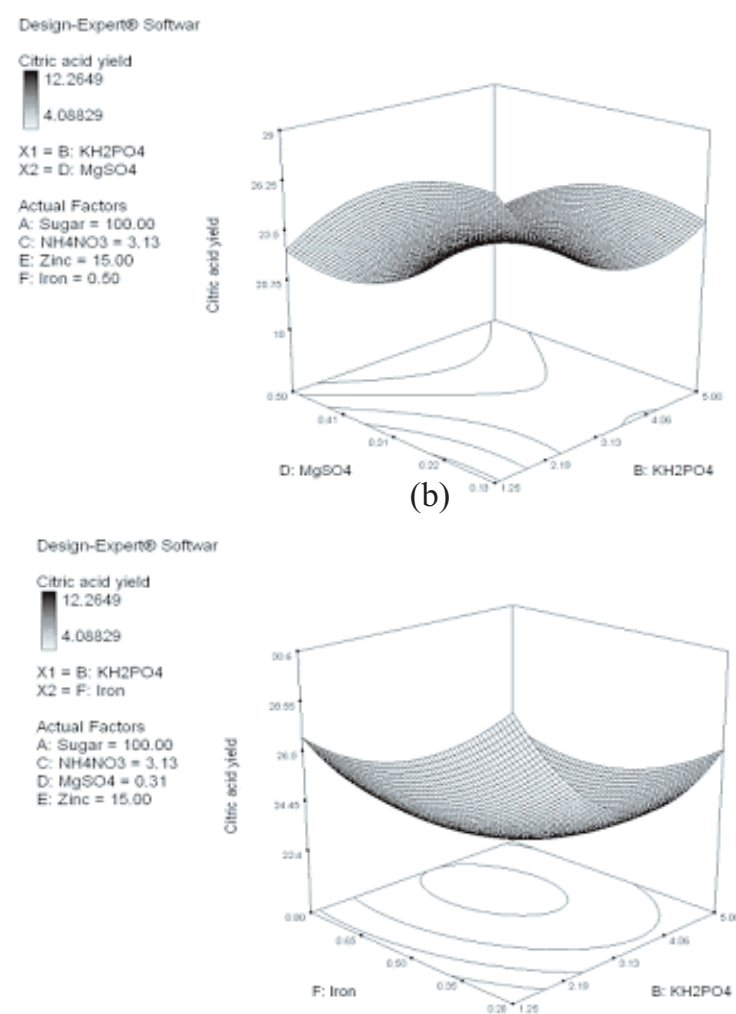

(b)

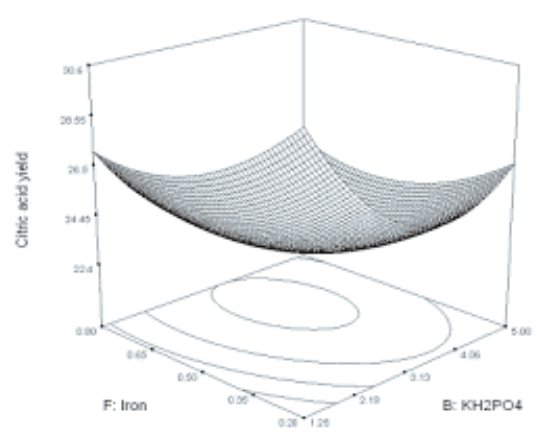

(d)

Fig. 3: Response surface and contour plot showing effect of sucrose in combination with other nutrient factors on citric acid yield by Aspergillus niger PCSIR-06
a) $\mathrm{KH}_{2} \mathrm{PO}_{4}+\mathrm{NH}_{4} \mathrm{NO}_{3}$
b) $\mathrm{KH}_{2} \mathrm{PO}_{4}+\mathrm{MgSO}_{4}$,
c) Sucrose $+\mathrm{Zn}$ d) Sucrose + Fe 
Design-Expertes Sortwar

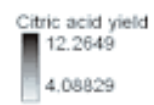

$\mathrm{X} 1=\mathrm{C}: \mathrm{NH}_{4} \mathrm{NO}_{3}$

$\mathrm{X}_{2}=\mathrm{D}: \mathrm{MgSO}$

Actual Factors

A. Sugat $=100.00$

B. KH.PO $4=3$. 13

E: Zinc $=15.00$

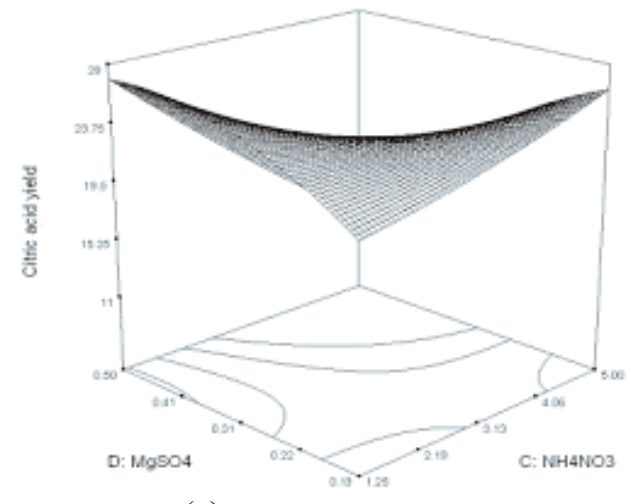

(a)

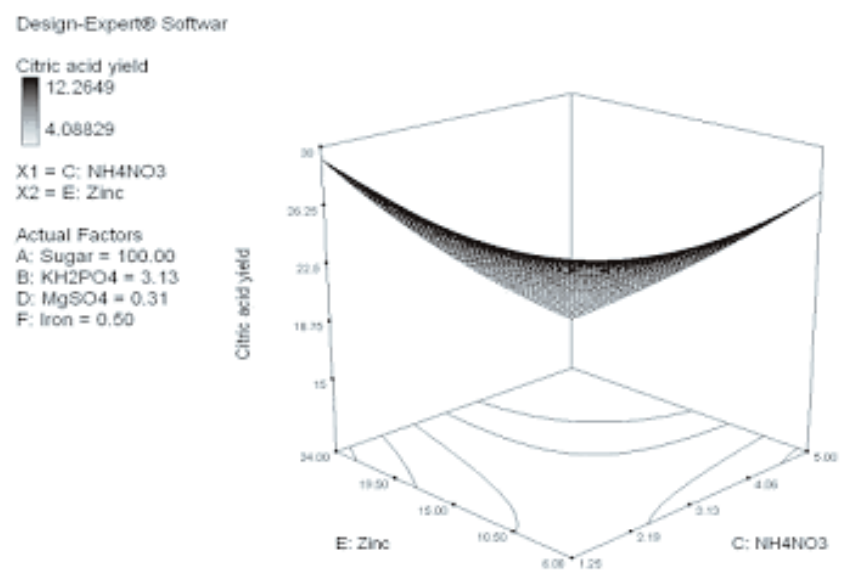

(b)

$$
\begin{aligned}
& \text { Design-Expento Softwar } \\
& \text { Citric acid yield } \\
& 12.2649 \\
& 4.05829 \\
& X 1=\text { C: NH4NO3 } \\
& \text { X2 }=\text { F: Iron } \\
& \text { Actual Factors } \\
& \text { A: Sugar }=100.00 \\
& \text { B: KH2POA }=3.13 \\
& \text { D: MgSO4 }=0.31 \\
& \text { E: Zinc }=15.00
\end{aligned}
$$

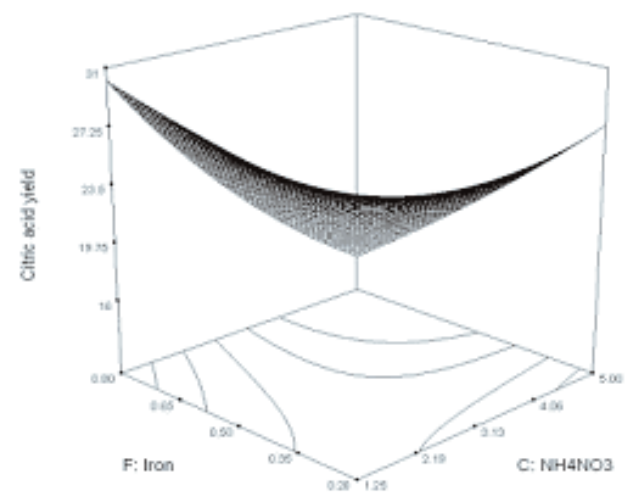

(c)

Fig. 4: Response surface and contour plot showing effect of $\mathrm{NH}_{4} \mathrm{NO}_{3}$ in combination with other nutrient factors on citric acid yield by Aspergillus niger PCSIR-06
a) $\mathrm{NH}_{4} \mathrm{NO}_{3}+\mathrm{MgSO}_{4}$,
b) $\mathrm{NH}_{4} \mathrm{NO}_{3}+\mathrm{Zn}$
c) $\mathrm{NH}_{4} \mathrm{NO}_{3}+\mathrm{Fe}$

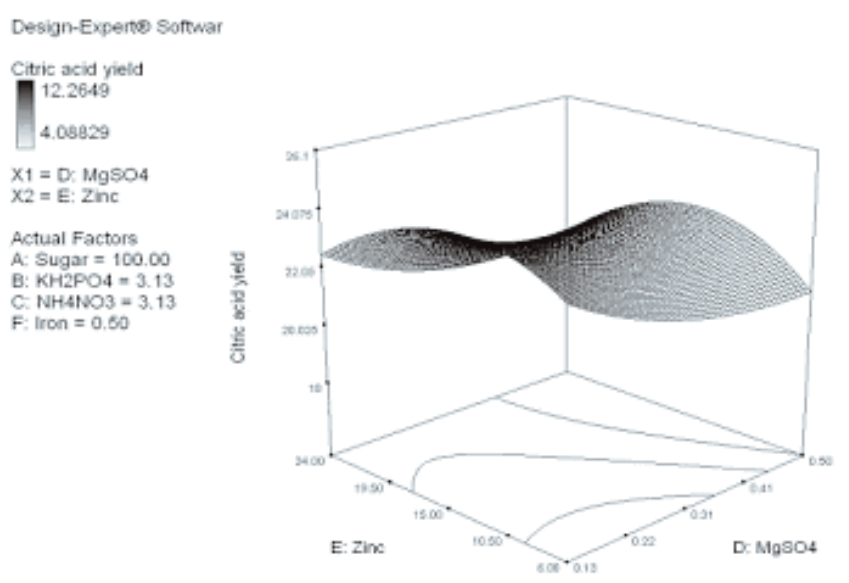

(a)

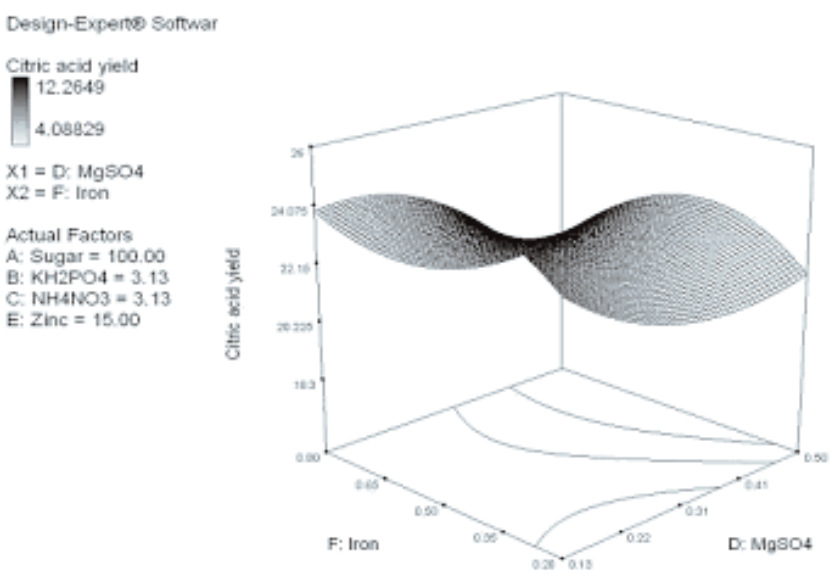

(b)

Fig. 5: Response surface and contour plot showing effect of $\mathrm{MgSO}_{4}$ in combination with other nutrient factors on citric acid yield by Aspergillus niger PCSIR-06
a)
$\mathrm{MgSO}_{4},+\mathrm{Zn}$
b) $\mathrm{MgSO}_{4}+\mathrm{Fe}$ 
Table III: Analysis of variance (ANOVA) for the quadratic model for citric acid yield

\begin{tabular}{|c|c|c|c|c|c|}
\hline Source & $\begin{array}{l}\text { Sum of } \\
\text { squares }\end{array}$ & $\mathrm{df}$ & Mean square & F - Value & $\begin{array}{l}\text { p-value } \\
\text { Prob }>\text { F }\end{array}$ \\
\hline Model & 49118.78 & 27 & 1819.214226 & 27.21075 & $<0.0001$ \\
\hline A-Sugar & 26253.95 & 1 & 26253.95101 & 392.6913 & $<0.0001$ \\
\hline $\mathrm{B}-\mathrm{KH}_{2} \mathrm{PO}_{4}$ & 39.11773 & 1 & 39.117734 & 0.5851 & 0.4512 \\
\hline $\mathrm{C}-\mathrm{NH}_{4} \mathrm{NO}_{3}$ & 113.335 & 1 & 113.3349525 & 1.695198 & 0.2043 \\
\hline $\mathrm{D}-\mathrm{MgSO}_{4}$ & 78.56772 & 1 & 78.56771502 & 1.17517 & 0.2883 \\
\hline E-Zinc & 42.21523 & 1 & 42.21522973 & 0.631431 & 0.4340 \\
\hline F-Iron & 25.1164 & 1 & 25.11640356 & 0.375677 & 0.5453 \\
\hline $\mathrm{AB}$ & 1.907194 & 1 & 1.907194475 & 0.028527 & 0.8672 \\
\hline $\mathrm{AC}$ & 0.503739 & 1 & 0.503738735 & 0.007535 & 0.9315 \\
\hline $\mathrm{AD}$ & 20.09994 & 1 & 20.09994222 & 0.300643 & 0.5882 \\
\hline $\mathrm{AE}$ & 39.76439 & 1 & 39.76439379 & 0.594773 & 0.4475 \\
\hline $\mathrm{AF}$ & 75.45466 & 1 & 75.45466419 & 1.128607 & 0.2978 \\
\hline $\mathrm{BC}$ & 72.35162 & 1 & 72.35162453 & 1.082194 & 0.3078 \\
\hline $\mathrm{BD}$ & 7.634949 & 1 & 7.634949267 & 0.114199 & 0.7381 \\
\hline $\mathrm{BE}$ & 18.06053 & 1 & 18.0605292 & 0.270139 & 0.6076 \\
\hline $\mathrm{BF}$ & 2.152658 & 1 & 2.152658044 & 0.032198 & 0.8590 \\
\hline $\mathrm{CD}$ & 235.1543 & 1 & 235.154306 & 3.517302 & 0.0720 \\
\hline $\mathrm{CE}$ & 145.6931 & 1 & 145.6931008 & 2.179193 & 0.1519 \\
\hline $\mathrm{CF}$ & 288.0419 & 1 & 288.0418513 & 4.308363 & 0.0480 \\
\hline $\mathrm{DE}$ & 0.000522 & 1 & 0.000522421 & 7.81E-06 & 0.9978 \\
\hline DF & 1.87795 & 1 & 1.877949785 & 0.028089 & 0.8682 \\
\hline $\mathrm{EF}$ & 187.5719 & 1 & 187.5718981 & 2.805591 & 0.1059 \\
\hline$A^{2}$ & 4805.703 & 1 & 4805.703251 & 71.88092 & $<0.0001$ \\
\hline $\mathrm{B}^{2}$ & 82.69619 & 1 & 82.69618826 & 1.236922 & 0.2762 \\
\hline $\mathrm{C}^{2}$ & 1.469401 & 1 & 1.469400545 & 0.021978 & 0.8833 \\
\hline $\mathrm{D}^{2}$ & 25.23687 & 1 & 25.23687393 & 0.377479 & 0.5443 \\
\hline$E^{2}$ & 5.399127 & 1 & 5.399127091 & 0.080757 & 0.7785 \\
\hline $\mathrm{F}^{2}$ & 14.22931 & 1 & 14.22931036 & 0.212834 & 0.6484 \\
\hline Residual & 1738.268 & 26 & 66.85645369 & & \\
\hline Lack of Fit & 1738.268 & 21 & 82.77465695 & & \\
\hline Pure Error & 0 & 5 & 0 & & \\
\hline Cor Total & 50857.05 & 53 & & & \\
\hline Std. Dev. & 8.17658 & & R-Squared & 0.965821 & \\
\hline Mean & 35.66168 & & Adj R-Squared & 0.930326 & \\
\hline C.V. $\%$ & 22.92819 & & Pred R-Squared & 0.786623 & \\
\hline PRESS & 10851.73 & & Adeq Precision & 16.78523 & \\
\hline
\end{tabular}


$\mathrm{MgSO}_{4}$ ) (Fig. 6) revealed that maximum yield of citric acid could be achieved by keeping one of the both metals at minimum and other at maximum level in the medium. The trace metal have important role in accumulation of citric acid (Shu and Johnson (1948). They synergistically influence on yield of citric acid (Kristiansen and Sinclair, 1979).
Olama, 2002; Chang et al., 2002; El-Helow et al., 2000; Francis et al., 2003).

\section{Conclusion}

It can be safely concluded from the aforsaid study that the application of Box-Bhenken design and response surface

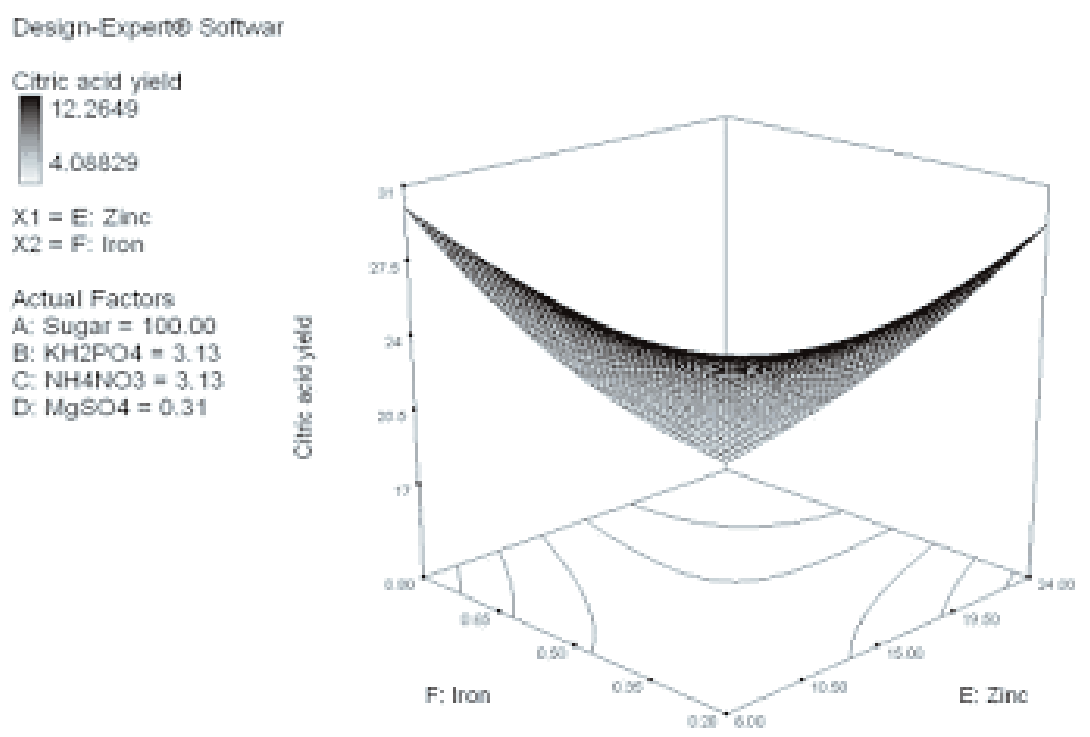

Fig. 6: Response surface and contour plot showing effect of Fe and $\mathrm{Zn}$ on citric acid yield by Aspergillus niger PCSIR-06

On the basis of above described relationships among the experimental factors, the Model predicted optimized concentrations of medium ingredients i.e., Sucrose $149.92 \mathrm{~g} / \mathrm{l}$, $\mathrm{KH}_{2} \mathrm{PO}_{4} 1.25 \mathrm{~g} / 1, \mathrm{NH}_{4} \mathrm{NO}_{3}, 4.66 \mathrm{~g} / 1, \mathrm{MgSO}_{4} 0.15 \mathrm{~g} / \mathrm{l}, \mathrm{Zn}$ $24.00 \mathrm{mg} / \mathrm{l}, \mathrm{Fe} 0.21 \mathrm{mg} / \mathrm{l}$ for maximum citric acid yield i.e., $108.69 \mathrm{~g} / 1$.

\section{Verification}

A verification run was conducted in triplicate to confirm the predicted optimized concentrations of the medium ingredients using Aspergillus niger PCSIR 06 with requisite conditions. The mean citric acid yield of $102.18 \pm 2.38 \mathrm{~g} / 1$ was obtained with the optimized concentrations of medium ingredients which is quite close to predicted yield of 108.69 $\pm 2.92 \%$. The application of response surface methodology to optimize the medium composition for various processes has also been reported by many workers (Abdel-Fateh and analysis to optimize the different factors for maximal production is an efficient method that evaluates the interactive effect of each factor. Further it converts the bioprocess factors correlation into a mathmetical model that predicts where the optimum is likely to be located.

\section{References}

Abdel-Fattah Y. R. and Olama Z. A. L. (2002). Aspariginase production by Pseudomonas aeruginosa in soid state cuture. Evauation and optimization of culture conditions using factorial designs. Proc. Biochem. 38: 115-122.

Box G. E. P. and Behnken D. W. (1960). Some new three level design for the study of quantitative variables. Technometerics 2: 455-475.

Chang Y. N., Huangs J. C., Lee C. C., Shih I. L. and Treng Y. M. (2002). Use of response surface methodology to 
optimize cuture medium for production of lovastatin by Monascus rubber. Enz. Microbial Technol. 30: 320327

Deshayes C. M. P. (1980). Utilisation de modeles mathematiques pour $\mathrm{i}$ optimization en fermentation, applications aux transformations par les micro-organimes, Bull. Sac. Chim. Fr., 1, 24.

El-Helow E. R., Abdel-Fattah Y. R., Ghanem K. M. and Mohammad E. A. (2000). Application of the response surface methodology for optimizing the activity of an aprE-driven gene expression system in Bacillus subtilis. Appl. Microbiol. Biotechnol. 54: 515-520.

Foster J. W. (1949). Chemical activities of fungi. Academic Press, New York.

Francis F., Sabu A., Nampoothiri K. M., Ramachandran S., Ghosh S., Szakacs G. and Pandey A. (2003). Use of response surface methodology for optimising process parameters for the production of $\alpha$-amylase by Aspergillus oryzae. Biochem. Eng. J. 15: 107-115.

Gadd G. M. (2004). Mycotransformation of organic and inorganic substrates, Mycologist, 18(2): 60-70.

Gupta R., Beg, Q. K., Khan, S. and Chauhan, B. (2002). An overview on fermentation, downstream processing and properties of microbial proteases. App. Microbiol. Biotechnol. 60: 381-395.

Haaland P. D. (1989). Statistical problem solving. In P. D. Haaland (ed). Experimental Design in Biotechnology. Marcel Dekker, Inc., New York, pp. 1-18.

Hang Y. D. and Woodams E. E. (1998). Production of citric acid from comcobs by Aspergillus niger. Bioresour. Technol. 65: 251-253.

Jianlong W. (2000). Production of Citric Acid by Immobilized Aspergillus niger Using a Rotating Biological Contactor (RBC), Bioresource Technology, 75: 245-247.

Kristiansen B. and Sinclair C. G. (1978). Production of citric acid in batch culture. Biotechnol. Bioeng. 20: 17111722 .
Kristiansen B. and Sinclair C. G. (1979). Production of citric acid in continuous culture. Biotechnol. Bioeng. 21: 297-315.

Marier J. R. and Boulet M. (1956). Direct determination of citric acid in milk by an improved pyridine acetic anhydride method. J. Dairy Sci. 41: 1683-1692.

Metthews R. J., Scott R. G. and Morgan S. L. (1981). Characterization of an enzymatic determination of arsenic (V) based on response surface methodology, Anal. Chim. Acta, 33: 169.

Pandey A., Soccol C. R., Rodriguez-León J. A. and Nigam P. (2001). Production of Organic Acids by Solidstate Fermentation. In: Solid-state Fermentation in Biotechnology - Fundamentals and Applications. New Delhi: Asiatech Publishers, Inc., 113-126.

Papagianni M., Wayman F. and Mattey M. (2005). Fate and role of ammonium ion during fermentation of citric acid by Aspergillus niger. Applied and Experimental Microbiology 71: 7178-7186.

Rahman M., Kayani S. A., Haq M. Z. and Gul S. (2008). Biorecovery of manganese from pyrolusite ore using Aspergillus niger PCSIR-06. J. Chem. Soc. Pak. 30: 203-208.

Röhr M., Kubicek C. P. and Komínek J. (1983). Citric Acid. In: Reed, G., Rehm, H. J. (Eds.). Biotechnology, vol. 3. Weiheim: Verlag Chemie, pp. 419-454.

Roukas T. (1999). Citric acid production from carob pod by solid-state fermentation, Enzyme Microb. Tech. 24: 5459.

Roukas T. and Kotzekidou P. (1997). Pretreatment of date syrup to increase citric acid production, Enzyme Microb. Technol. 21: 273-276.

Sarangbin S., Krimura K. and Usami S. (1993). Citric acid production from cellobiose by 2-deoxyglucose-resistant mutant strains of Aspergillus niger in semi-solid culture. Appl. Microbiol. Biotechnol. 40(2-3): 206210 . 
Shankaranand V. S. and Lonsane B. K. (1994). Ability of Aspergillus niger to tolerate metal ions and minerals in a solid-state fermentation system for the production of citric acid Process Biochem. 29: 29-37.

Shu P. and Johnson M. J. (1948). Citric acid production by submerged fermentation with Aspergillus niger. Ind. Eng. Chem. 40: 1202-1205.

Soccol C. R., Prado F. C., Vandenberghe L. P. S. and Pandey A. (2003). General Aspects in Citric Acid production by Submerged and Solid-state Fermentation. In: Encyclopedia on Bioresource Technology. Haworth Press, New York: pp. 652-664.
Suzuki A., Sarangbin S., Krimura K. and Usami S. (1996). Direct production of citric acid from starch by a 2deoxyglucose-resistant mutant strain of Aspergillus niger J. Ferment. Bioeng. 81(4): 320-323.

Vandenberghe L. P. S., Soccol C. R., Pandey A. and Lebeault J. M. (2000). Solid-state Fermentation for the Synthesis of Citric Acid by Aspergillus niger, Biores. Technol. 74: 175-178.

Yokoya F. (1992). Fermentação cítrica, vol. 1, Campinas SP: Fundação Tropical de Pesquisas e Tecnologia André Tosello, p. 79.

Received: June 20, 2010;

Accepted : November 29, 2010 